Proceedings of the Second Annual Forestry Symposium 1996: Management and Sustainable Utilization of Forest Resources, Sri Lanka, 6-7 December 1996. (Eds. Amarasekera, HS, Ranasinghe, D M S HK and Finlayson, W). Published by Department of Forestry and Environmental Science, University of Sri Jayewardenepura, Sri Lanka (1998)

\title{
PRELIMINARY GROWTH PERFORMANCE OF Eucalyptus microcorys PROVENANCES IN THE UP-COUNTRY INTERMEDIATE AND WET ZONES
}

\author{
K.M.A. Bandara \\ Forest Department
}

\begin{abstract}
Eucalyptus microcorys is the main forest plantation species producing high quality timber in the wet and intermediate zones of the up-country of Sri Lanka. Verv few attempts have been made in the past to select genotypes of this species for better growth and timber yield. Two field trials have now been made with six seedlots from the CSIRO, Australia. The first experiment, at Dixon's Corner in the up-country wet zone, showed that the provenance "NW of Wauchope" (New" South Wales) performed well compared with the local landrace. The second experiment was established in both the dry and wet zones of the up-country. The provenances "Kendall" from New South Wales and " $11 \mathrm{~km} W$ of Beerbu" from Queensland performed well in the wet zone, compared with the other tested provenances, but in the intermediate zone the growth rates of the imported provenances did not show any remarkable differences from that of the local landrace.
\end{abstract}

\section{Introduction}

Eucalyptus microcorys F.Muell is naturally distributed in northern coastal New South Wales, and in southeastern Queensland between the coastal zone and the higher altitudes (Boland et al. 1984). It was introduced to Sri Lanka in 1880 and has been used as a plantation tree in the up-country wet zone since 1930 (Webb et al. 1984; Streets, 1962). According to Bandarathilaka (1994) 700-800 ha have been planted, it is planned to make more plantations with this species under the reforestation programme, and many plants will also be raised for home gardens and farm woodlots. The timber is in high demand for heavy construction work, because of its high density, durability and workability. Even though a fairly long rotation of 30-35 years is needed, farmers like to plant it in their home gardens because of the eventual high economic return.

In the past no improvement work was done on E. microcoryd in Sri Lanka, because it was not considered to be a priority species. In an early attempt to improve the seed sources. existing plantations of good performance were identified in the up-country intermediate and wet zones, at Diyatalawa and Dansinan respectively. They were selectively thinned to form seed-production stands. The seed origin of these plantations is not known. 
The study reported here tested different provenances from Australia. Preliminary results are now available.

\section{Materials and methods}

\section{Experiment 1}

Seed of eleven provenances of $E$. microcorys were received from CSIRO, Australia and were sown in the departmental nursery at Mahakudugala, Nuwara Eliya. Because of the very poor germination of the seedlots, only three provenances gave sufficient seedlings to use in the experiment. Table I lists the provenances used. ie the three from Australia and a local collection of E. grandis for comparison.

\section{Table 1 : Description of seedlots used in Experiment 1}

\begin{tabular}{cclccc}
\hline & Scedlot No. & Provenance & Lat. & Long. & $\begin{array}{c}\text { Alt. } \\
(\mathrm{m})\end{array}$ \\
\hline 1 & 17136 & Kenilworth State Forest, Qld. & $26^{\circ} 41^{\prime} \mathrm{S}$ & $152^{\circ} 35^{\prime} \mathrm{E}$ & 650 \\
2 & 13972 & NW of Wauchope, NSW & $31^{\circ} 13^{\prime} \mathrm{S}$ & $152^{\circ} 21^{\prime} \mathrm{E}$ & 760 \\
3 & 15250 & Nambour, Qld. & $26^{\circ} 40^{\prime} \mathrm{S}$ & $152^{\circ} 55^{\prime} \mathrm{E}$ & 45 \\
4 & Local & E. grandis, Mahakudugala & $7^{\circ} 08^{\prime} \mathrm{N}$ & $80^{\circ} 81^{\prime} \mathrm{E}$ & 105 \\
& & & & 0 \\
\hline
\end{tabular}

These provenances were planted in 1992 at Dixon's Comer in Nuwara Eliya District, in a randomized complete block design with three replications. The spacing was $2.5 \times 2.5 \mathrm{~m}$, in 25 -trce plots. Table 2 gives a description of the locality.

\section{Table 2: Particulars of the trial site, Experiment 1}

$\begin{array}{ll}\text { Location: } & \text { Dixon's corner, Nuwara Eliya } \\ \text { Latitude: } & 7^{\circ} 8^{\prime} \mathrm{N} \\ \text { Longitude: } & 81^{\circ} 8^{\prime} \mathrm{E} \\ \text { Altitude: } & 1350 \mathrm{~m} \\ \text { Soil: } & \text { Red-yellow podzolic, quite deep and fertile } \\ \text { Mean annual rainfall: } & >2000 \mathrm{~mm} \\ \text { Site condition: } & \text { E. grandis clear-felling site }\end{array}$

Two years after planting, it was observed that some seedlots been mixed with local $E$. grandis. The mixing could have happened in the nursery; the soil use had been collected from the adjoining $E$ grandis plantation and could have contained seed.

The E. microcorys trees were separated from $E$. grandis trees, and tree height and dbh were measured four years after planting. Because of the missing data, general linear modelling was used to compare variation between provenances. 


\section{Experiment 2}

Another five seedlots of E. microconys were received from CSIRO, but ony three were germinated and were used in Experiment 2, along with two local seedlots. Table 3 gives the provenance information.

Table 3 : Description of seedlots used in experiment 2

\begin{tabular}{cllllc} 
& Seedlot No. & Provenance & Lat. & Long. & Alt. (m) \\
\hline 1 & 13971 & NNE of Kendall, NSW & $31^{\circ} 34^{\prime} \mathrm{S}$ & $152^{\circ} 47^{\prime} \mathrm{E}$ & 40 \\
2 & 15527 & Kendall, NSW & $31^{\circ} 34^{\prime} \mathrm{S}$ & $152^{\circ} 41^{\prime} \mathrm{E}$ & 180 \\
3 & 15607 & $11 \mathrm{~km}$ W of Beerbu, Qld. & $26^{\circ} 56^{\prime} \mathrm{S}$ & $152^{\circ} 52^{\prime} \mathrm{E}$ & 120 \\
4 & Local & E.microcorys, Erabedda & $6^{\circ} 9^{\prime} \mathrm{N}$ & $81^{\circ} 8^{\prime} \mathrm{E}$ & 1000 \\
5 & Local & E. grandis, Erabedda & $6^{\circ} 9^{\prime} \mathrm{N}$ & $81^{\circ} 8^{\prime} \mathrm{E}$ & 1000 \\
\hline
\end{tabular}

The seeds were sown in the nursery at Agaratenna, Badulla. The initial growth in the nursery was excellent. Planting was in complete randomized blocks with four replications, in two different up-country ecological sites representing the intermediate and wet zones. Table 4 gives descriptions of the localities.

Table 4 : Particulars of the trial site, Experiment 2

\begin{tabular}{|c|c|c|c|}
\hline & & Site 1 & Site 2 \\
\hline 1 & Location and climatic zone & $\begin{array}{l}\text { Up intermediate, } \\
\text { Erabedda }\end{array}$ & $\begin{array}{l}\text { Up wet, } \\
\text { Mahakudugalla }\end{array}$ \\
\hline 2 & Latitude and longitude & $6^{\circ} 9^{\prime} \mathrm{N}, 81^{\circ} \mathrm{I}^{\prime} \mathrm{E}$ & $6^{\circ} 8^{\prime} \mathrm{N}, 80^{\circ} 9^{\prime} \mathrm{E}$ \\
\hline 3 & Altitude, metres & 950 & 1550 \\
\hline 4 & Soil group and condition & $\begin{array}{l}\text { Red-yellow podzolic, } \\
\text { fairly degraded, } \\
\text { shallow }\end{array}$ & $\begin{array}{l}\text { Red-yellow podzolic, } \\
\text { fertile and quite deep }\end{array}$ \\
\hline 5 & Mean annual rainfall, mm & $1750-2000$ & $>2000$ \\
\hline 6 & Site condition & Abandoned tea land & $\begin{array}{l}\text { E.grandis clear-felling } \\
\text { site }\end{array}$ \\
\hline
\end{tabular}

The trials in both locations were planted in November 1994, during the northeast monsoon. All treatments were planted at a spacing of $2.5 \times 2.5 \mathrm{~m}$, in 25 -tree plots. Four weedings were done in the first two years and a general fertilizer mixture was applied, at the rate of $50 \mathrm{~g}$ per plant, at the beginning of each monsoonal rains. 
An assessment was made of survival two months after planting, and a preliminary growth assessment, in terms of tree height and dbh, two years after planting, in 1996.

\section{Results and discussion}

\section{Experiment 1}

Table 5 shows the results four years after planting. General linear modelling was done to test the variation between provenances and Duncan's range test was used to compare the treatment mean differences.

There is a significant difference between E. grandis and E. microcorys. The provenance "NW of Wauchope" from a high altitude area of NSW performed well in regard to height growth, compared with the other tested provenances.

Table 5: Height and dbh 4 years after planting, Experiment 1

\begin{tabular}{|c|c|c|c|c|c|}
\hline Seedlot No. & Provenance & $\begin{array}{l}\text { Mean total } \\
\text { height (m) }\end{array}$ & $\begin{array}{l}\text { Duncan } \\
\text { 's test }\end{array}$ & $\begin{array}{l}\text { Mean } \\
\text { dbh } \\
(\mathrm{cm})\end{array}$ & $\begin{array}{l}\text { Duncan's } \\
\text { test }\end{array}$ \\
\hline 13972 & $\begin{array}{l}\text { NW of Wauchope, } \\
\text { NSW }\end{array}$ & 9.63 & $a b$ & 8.2 & $a b$ \\
\hline 15250 & Nambour. Qld. & 8.34 & $a b$ & 8.8 & $a b$ \\
\hline 17136 & $\begin{array}{l}\text { Kenilworth State } \\
\text { Forest, Qld. }\end{array}$ & 6.54 & $\mathrm{~b}$ & 6.5 & b \\
\hline Local & $\begin{array}{l}\text { E. grandis, Newara } \\
\text { Eliya }\end{array}$ & 12.4 & a & 10.6 & a \\
\hline Probability & & 0.06 & & 0.07 & \\
\hline CV\% & & 18.56 & & 15 & \\
\hline
\end{tabular}

\section{Experiment 2}

Height and dbh were measured at both sites two years after planting. The ANOVA test was applied to the results. The site factor/provenance interaction in the combined analysis was significant at the probability level of $95 \%$ (Table 6 ).

Table 6: Results of the combined analysis

\begin{tabular}{lllll}
\hline Source & Df & Ms & Fval & Pr> F \\
\hline Site & 1 & 110.82 & 1518.62 & 0.001 \\
Block & 3 & 0.12 & 1.7 & 0.19 \\
Provenance & 4 & 2.5 & 34.27 & 0.0001 \\
Site $\times$ prov. & 4 & 0.78 & 10.74 & 0.0001 \\
\hline \multirow{2}{*}{$:$} \\
:
\end{tabular}


Annual Forestry Symposium, 1996

Because of the significance of the interaction between sites and provenances, two separate analyses were performed for both sites. The results are given in Table 7

On both sites the growth of $E$. grandis was significantly greater than that of $E$. microcorys. Both species showed significantly different yields (probability 0.0001 ) in the different climatic zones. The mean height and dbh at Mahakudugala two years after planting were $4.25 \mathrm{~m}$ and $6.43 \mathrm{~cm}$, while at Erabedda they were only $0.93 \mathrm{~m}$ and $1.5 \mathrm{~cm}$. A survival assesment four months after planting was done.

In the up-country wet zone at Mahakudugala all provenances from Australia performed well compared with the local landrace. The Kendall provenance from New South Wales (15527) outperformed the other provenances tested. It seems that in this zone high-altitude and highlatitude provenances perform well compared with those from lower altitudes and lower latitudes.

Table 7: Height and dbh growth of different provenances of $E$. microcorys and $E$. grandis at Erabedda and Mahakudugalla (Experiment 2)

\begin{tabular}{cccccc}
\hline & & \multicolumn{2}{c}{ Erabedda } & \multicolumn{2}{c}{ Mahakudugula } \\
\hline $\begin{array}{c}\text { Seedlot } \\
\text { No. }\end{array}$ & Provenance & $\begin{array}{c}\text { Mean height } \\
(\mathbf{m})\end{array}$ & $\begin{array}{c}\text { Mean dbh } \\
(\mathbf{c m})\end{array}$ & $\begin{array}{c}\text { Mean height }(\mathbf{m}) \\
\begin{array}{c}\text { Mean } \\
\mathbf{d b h} \\
(\mathbf{c m})\end{array}\end{array}$ \\
\hline 13971 & NNE of Kendall, NSW & $0.97 \mathrm{~b}$ & $1.4 \mathrm{~b}$ & $3.86 \mathrm{bc}$ & $5.87 \mathrm{~b}$ \\
15527 & Kendall, NSW & $0.88 \mathrm{~b}$ & $1.2 \mathrm{~b}$ & $4.26 \mathrm{~b}$ & $6.13 \mathrm{~b}$ \\
15607 & $11 \mathrm{~km}$ W of Beerbu, Q1d. & $0.83 \mathrm{~b}$ & $1.3 \mathrm{~b}$ & $3.98 \mathrm{bc}$ & $6.13 \mathrm{~b}$ \\
Local & E. microcorys & $0.67 \mathrm{~b}$ & $1.2 \mathrm{~b}$ & $3.45 \mathrm{c}$ & $5.65 \mathrm{~b}$ \\
Local & E. grandis & $1.35 \mathrm{a}$ & $2.45 \mathrm{a}$ & $5.73 \mathrm{a}$ & $8.35 \mathrm{a}$ \\
& Probability & 0.001 & 0.0001 & 0.0001 & 0.0004 \\
& CV \% & 17.6 & 16.61 & 8.22 & 9.84 \\
\hline
\end{tabular}

In the intermediate zone there was a significant difference between the two species, and all imported provenances of E. microcorys showed higher growth rates than the local landrace. but no significant differences could be found between the Australian provenances.

\section{Conclusions}

- E. microcorys is slow growing compared with $E$. grandis.

- The growth of E. microcorys in the up-country intermediate zone is much slower than in the up-country wet zone.

- The growth performances of different provenances of $E$. microcorys in both climatic zones are different, or else the site/provenance interaction is significant. 
- Provenances from high altitudes and high latitudes areas perform well in the upcountry wet zone. More provenances from those areas should be tested before a strong reconmendation is made for this particular area of Sri lanka.

- The provenances from Kendall, New South Wales; " $11 \mathrm{~km} \mathrm{~W}$ of Beerbu", Queensland; and "NW of Wauchope", New South Wales are promising provenances for the immediate seed requirements in the up-country wet zone reforestation areas.

- It is necessary to test more provenances of this specics in the up-country intermediate zone.

\section{Acknowledgement}

I wish to acknowledge the assistance of ATSC, CSIRO, Australia, in providing the necessary seeds to establish the field cxperiments. My especial thanks are due to Messrs Sarath Mahindasiri. Pusphakumara, and Ranjith, for their valuable help in the management of the trials and data collection.

\section{References}

Bandarathilaka, H.M. (1994). Administration Report for 1994. Forest Department, Sri Lanka.

Boland, D.J. et al. (1984). Forest trees of Australia.

Streets, R.J. (1962). Exotic forest trees in the British Commonwealth.

Webb, D.B. et al. (1984). A guide line to species selection for tropical and sub-tropical plantations. 